\title{
LOAD BEARING CAPACITY AND CRACKING RESISTANCE TO OFF-CENTER COMPRESSION OF HOLLOW CONCRETE BLOCKS
}

\author{
Lviv Polytechnic National University, \\ ${ }^{1,3}$ Department of Highways and Bridges, \\ ${ }^{2}$ Department of Building Constructions and Bridges, \\ ${ }^{4}$ Lviv National Agrarian University
}

CC Melnyk I., Bilozir V., Bidenko I., Shulyar R., and Partuta V., 2020

The research is about concrete hollow blocks that have been and still are used widely in basement wall construction. It shows that only 10-30 \% of their strength is used even for mid and high-rise construction. Therefore massive foundation blocks should be made with hollows. By design, optimized blocks can be combined into the following groups: with large cavities, open from below, with vertical closed and through cavities, horizontal cavities and ribbed.

The developed designs of effective blocks of walls of basements potentially give the chance to facilitate them considerably and to save concrete. However, almost of the proposed solutions have not been widely used in practice - mainly due to technological problems. It is necessary to continue the search for effective structural and technological solutions of basement wall blocks and their research.

The article shows the result of experimental and theoretic research of two types of concrete blocks: FBH-1 with two top opened hollows and FBH-2 with 4 enclosed hollows. FBH-2 block has hollows with arbolite insertions. His type is efficient for basement external wall due superior thermal performance.

The blocks were texted as a part of 3-storey masonry of $1.8 \mathrm{~m}$ height applying off-centric loads to it. Those texts allowed to get its actual strength capacity as well as cracking resistance.

The load bearing capacity and cracking resistance have been calculated using a deformation method according to current codes. The method takes into account an idealized diagram of concrete stretching.The calculations according to developed method showed satisfactory matching with experimental data of load bearing capacity and cracking resistance.

Key words: hollow foundation blocks, load bearing capacity, experimental research, deformation method, deformation diagram.

\section{Problematic}

When prefabricated concrete blocks became widely used for stripped foundation systems they proved to be more efficient in all aspects, comparing to previously popular rubble foundations. The usage of concrete blocks with reinforced footing allowed to reduce soil pleasure as well as narrow their width, from 80 to $30-60 \mathrm{~cm}$. However, even such system performs with a significant strength reserve. This is partly due to minimized width of the wall on top of foundation on one side, and due to lower concrete class which is usually selected not based on its strength but rather its durability (frost protection, waterproofing), technological reasons, etc.

As a result, the same blocks have been and still are used for both mid-rise and high-rise structures in which their strength is being used for only $10-30 \%$. 
There for more efficient foundation wall blocks are introduced to replace their solid counterparts, which usually are much more material consuming and less efficient.

Among all accessible structures for concrete blocks for foundation walls, the only standardized product is a massive foundation block with nominal sizes of $2.4 \mathrm{~m}$ long, $0.6 \mathrm{~m}$ high and 3, 4, 5 and $6 \mathrm{dm}$ wide, manufactured according to the standard of GOST 13579. These are FBH blocks with 13.2 to $28.6 \%$ hollowness depending of their typical size. However they are not widely used due to problems with their manufacturing techniques. A significan arear of contact of steel form with the blocks inner surface combined with compressing deformations during the settling do not allow for smooth uncasement as well as getting it out of the steel formwork.

\section{Research relevance}

The research is relevant because of important problems of material, energy and resource preservations (Malinina, 1985; Folomeev, 1985). The structural application for hollow blocks allows for significant reduction of mass material spending and in some cases to for incensement of thermal resistance. Ecological aspects are also relevant because of less sand, gravel and especially cement usage for the product manufacturing. (Reinforced concrete and ecology. Concrete and reinforced concrete, 1993).

\section{Existing researches and publications analysis}

Box section concrete blocks were used in construction of Hrebenkiv MTS in Kyiv region. Within the size of $2 \times 0.66 \times 05 \mathrm{~m}$ and 100 wide longitude walls, the block hollowness is up to $40 \%$ (Malyugin, 1958).

In search of efficient solutions for the ground zero construction a prefabricated complex structure for the subflooring part of the wall was suggested. The ribbed footing support the hollow boxed blocks and coned blocks with two horizontal hollows are installed on top of that. (Efficient zero cycle constructs for high-rise buildings. Concrete and reinforced concrete, 1975).

A sample testing of big size hollowed blocks (entire wall height block-panels) has been conducted on Lviv Concrete Factory No. 1. within the cooperation agreement between Lviv Polytechnic and Ternopil Regional Agro-Construction. (Report on NIR "Experimental study of hollow-core block panels of basement walls for residential and public buildings”. Lviv Polytechnic Institute, 1989). The blocks manufactured by Mykulyn "Budindustria" factory were in sizes of $0.4 \times 2.4 \times 2.4 \mathrm{~m}$ and comprise 6 cylindrical hollows of $28 \mathrm{~cm}$ in diameter. Load testing has shown their load bearing capacity under the least desirable loading conditions.

A number of researches on hollow concrete blocks with rational parameters were conducted in Kharkiv National Academy of Urban Maintenance. (Shmukler, 2007; Molodchenko, 2007; Burak, 2007).

Kabir Aklamur supervised by Schmuchler V. S. was studying tensed conditions of opened hollows concrete blocks aiming to optimize their geometric parameters by using conditions of both $\wedge$ force and exploitation. (Akramul, 1994). Under the actual experiment the corner fragment of the building foundation was constructed using suggested hollowed concrete blocks. During the experiment, the hollows were filled with water to imitate the conditions of water rich soils. The study took two months to observe the implications of possible non-forced factors and allowed to assess deformation of hollowed blocks and therefore their relevance.

Luhchenko O. I. has tested two blocks with sizes of $404(\mathrm{a}) \times 690(\mathrm{~b}) \times 575(\mathrm{~h}) \mathrm{mm}$, which had a bottom opened hollow of $160 \times 410 \times 483 \mathrm{~mm}$ accordingly. Two other solid concrete blocks with the same dimesions were tested to compare the results. Experimental results of centric load of crashing magnitude had a good match with theoretical estimations. The difference for hollowed blocks constituted $5.8 \%$ and 
$7.8 \%$. And opposite for solid blocks - the difference of theoretical estimation over the experimental crashing load was 7.8 and $7.9 \%$ accordingly. (Luhchenko, 2009).

Hollowed concrete structures are also described in the book (Tetior, 1991).

Other countries have a widely popular concrete wall elements manufactured by "Bau-Innovation" which have improved thermal (Bau-Innovation Gesellschaftmobil \& Co. KG. ISOPLUS-EXTRA, 1991).

\section{Research objective}

The objective of this study is to publish the results of experimental and theoretic researches, that showcase a developed method of hollowed concrete block calculations under off-centric compression, while accounting for the concretes stretched zone impact. The results of theoretical calculations are compared with the experimental results of load bearing capacity and cracking resistance. This kind of tension and deformation condition is common for the foundations that support external walls.

\section{Experimental research}

The test sample structure is shown on the Fig. 1.

The first block had two top opening hollows (Fig. 1, $a$ ), the second - four enclosed hollows with arbolite insertions (Melnyk; Melnyk, 1999; Pankiv, 1999).
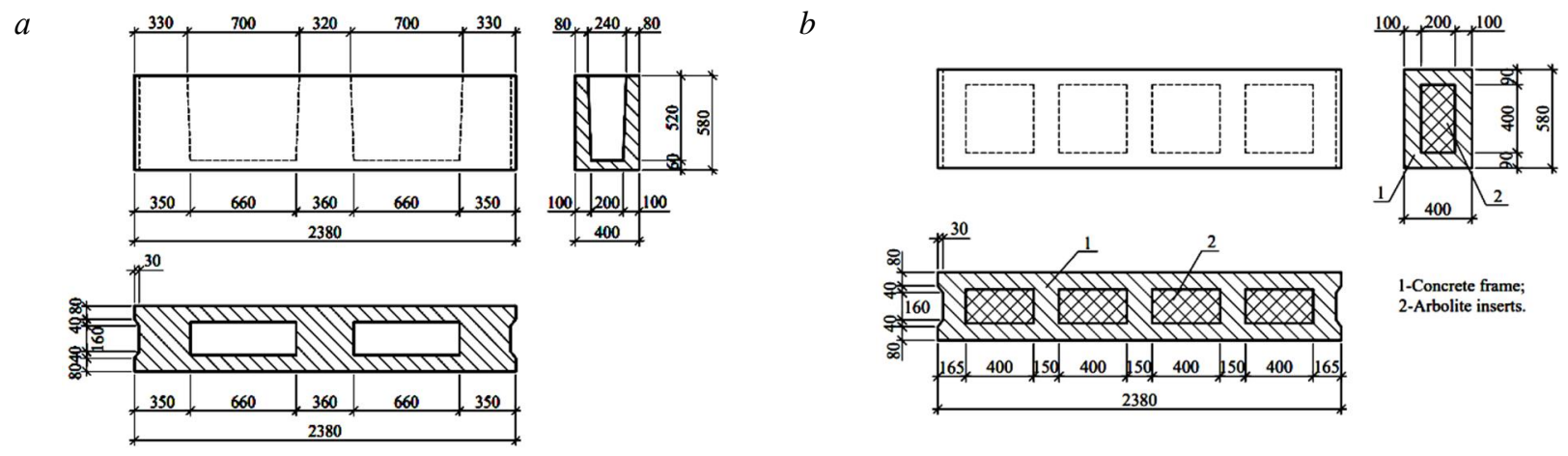

Fig. 1. Test samples structure

The samples were tested as a 3-level wall (Fig. 2). The first (lower) level in most layouts was supportive and served to establish a required height of the wall fragment, making it as high as the basement wall. At the same time it helped to install the equipment to observe the main test block which always was installed in the second row. During the test of FBH-1 block the lower level was made of structurally similar half blocks with seam overlaying, thus imitating the real performance conditions.

$a$

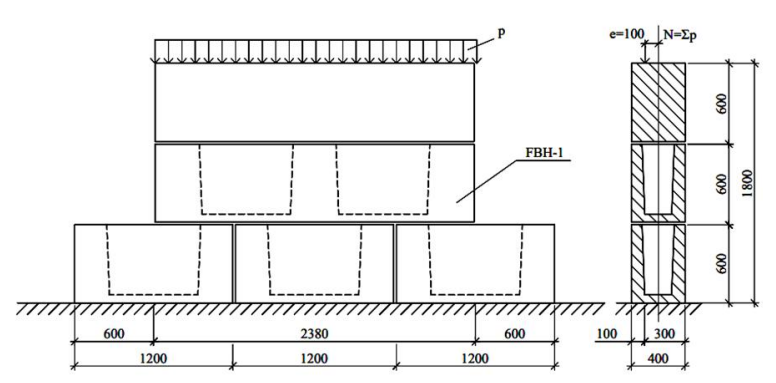

$b$

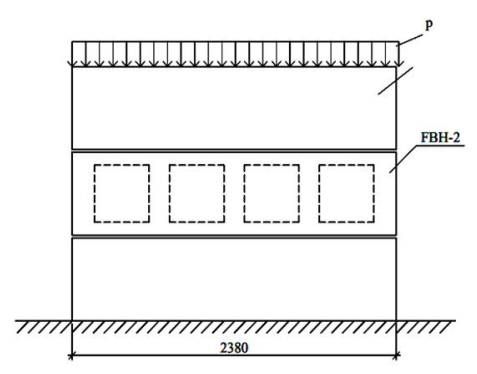

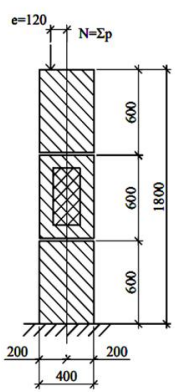

Fig. 2. Test block layouts: $a-F B H-1$ block; $b-F B H-2$ block 
The third row of blocks is installed in order to distribute loads from hydraulic jack to the middle row. It was solid in all rows. It it was also used to compare performance results with the main hollow block.

During the installation of each fragment, the blocks of every row were laid out using M300 mortar with 20-25 mm seams. This provided a firm and evenly distributed contact between neighboring block surfaces. In order to distribute the loads evenly the upper level of mortal was covered with $22 \mathrm{~mm}$ sheet and steel list and steel traverses on top of it.

The collapse of FBH-1 block was caused by the concrete fracturing of compressed zone along most of its rib longitude which contacted with the lower block. While collapsing, the upper block has got cracks of 1.2-2.5 mm thickness and 1.5-2.0, in the FBH-1 block. When the load reached a magnitude of $1896.2 \mathrm{kN}$ the FBH-1 test block has got horizontal cracks. The overall collapsing load for the FBH-1 block constituted $2075 \mathrm{kN}$.

The collapse of the FBH-2 occurred under the load of $\mathrm{N}=2286 \mathrm{kN}$ as a result of cracks in the longitude and the butt wall of the side hollow as well as fracturing of the compressed concrete below it. The occurrence of horizontal cracks in stretched longitude wall caused by $\mathrm{N}=1988.7 \mathrm{kN}$ is common for this type of block. The more detailed relents of this test are published in the article (Melnyk, 2009).

\section{Theoretic research}

Actual cross sections are brought to calculated T-shaped sections (Fig. 3).

The concrete's main mechanical characteristics were defined experimentally before the test. The FBH-1 block has got the following: cube strength $f_{\text {cube }}=8.3 \mathrm{MPa}$, cylindrical strenght $f_{c}=6.64 \mathrm{MPa}$, stretching resistance $f_{c t}=0.9 \mathrm{MPa}$, resilience module $E_{c}=14 \cdot 10^{3} \mathrm{MPa}$, concrete relative deformations, which refer to peak level of compression deformation diagram $\varepsilon_{\mathrm{c} 1}=1.53 \cdot 10^{-3}$. Concrete max deformation $\varepsilon_{c u 1}=4.6 \cdot 10^{-3}$. The FBH-2 block has the following numbers: $f_{c u b e}=7.8 \mathrm{MPa}, f_{c}=6.24 \mathrm{MPa}, f_{c t}=$ $=0.75 \mathrm{MPa}, E_{c}=12 \cdot 10^{3} \mathrm{MPa}, \varepsilon_{\mathrm{c} 1}=1.49 \cdot 10^{-3}$ Concrete max deformation $\varepsilon_{c u 1}=4.7 \cdot 10^{-3}$.

$a$
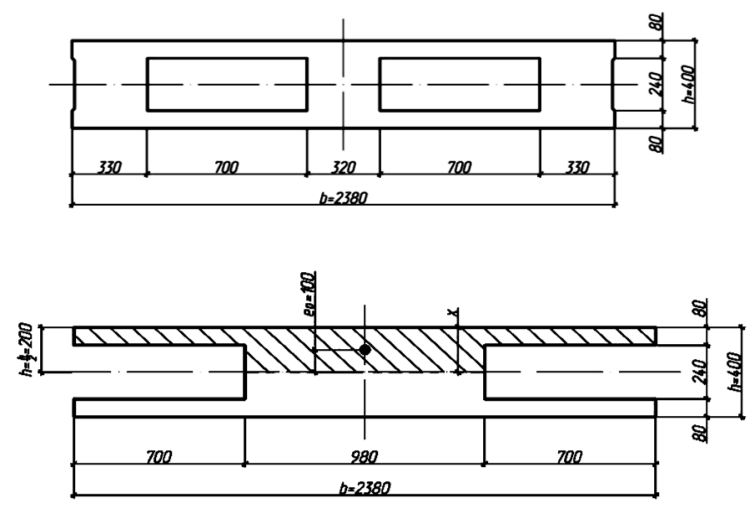

$b$
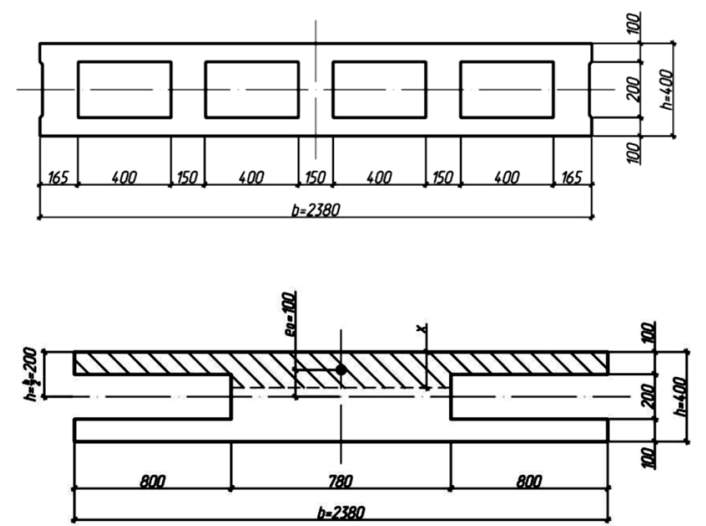

Fig. 3. Cross and calculated sections of foundation blocks ФБП-1 (a) and ФБП-2 (b)

These data are used to describe the concrete compressed deformation diagrams as polynomials of fifth stage, the factors $a_{k}$ of which has been defined by using the formulas presented in the publication (Bambura, 2006). The concrete stretched diagrams are not standardized yet, thus initial they've been accepted as polynomial with the same factors as in the case of compression. The diagrams for the deformation peak point were defined according to the standards (Bambura, 2006): $\varepsilon_{c t 1}=2 f_{c t} / E_{c}$. The dropping branch of the stretched deformation diagram was ignored, because under this leve of deformation the concrete simply collapses. 
The calculations show that a part or the whole lower plate stretches and develops crack when the load increases (Fig. 4).
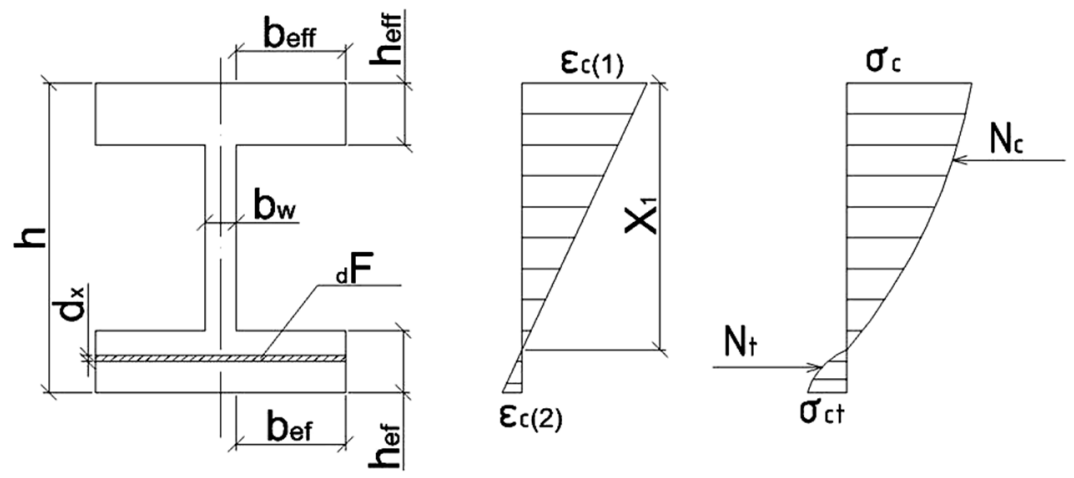

Fig. 4. Calculated section and diagrams of relative deformations and tensions for concrete blocks

Before crack occurrence the inner tension inside the stretched zone located in the calculated section's lower plate.

$$
\begin{gathered}
N_{t}=\int_{F} \sigma_{c t} d F=\int_{0}^{h-x_{1}} f_{c t}\left(2 b_{e f}+b_{w}\right) \sum_{k=1}^{5} a_{k}\left(\frac{\mathrm{N} x}{\varepsilon_{c t 1}}\right)^{k} d x= \\
=f_{c t}\left(2 b_{e f}+b_{w}\right) \sum \frac{a_{k}}{k+1}\left(\frac{\mathrm{N}}{\varepsilon_{c t 1}}\right)^{k}\left(h-\frac{\varepsilon_{c(1)}}{\mathrm{N}}\right)^{k+1},
\end{gathered}
$$

де $x_{1}=\frac{\varepsilon_{c(1)}}{\mathrm{N}}-$ height of the concrete compressed zone; $\mathrm{N}=\frac{\varepsilon_{\mathrm{c}(1)}+\varepsilon_{\mathrm{c}(2)}}{h}-$ curvature of the longitude axes.

Bending moment caused by this tension:

$$
\begin{gathered}
M_{t}=\int_{F} \sigma_{c t} x d F=\int_{0}^{h-x_{1}} f_{c t}\left(2 b_{e f}+b_{w}\right) \sum_{k=1}^{5} a_{k}\left(\frac{\mathrm{N} x}{\varepsilon_{c t 1}}\right)^{k} x d x= \\
=f_{c t}\left(2 b_{e f}+b_{w}\right) \sum \frac{a_{k}}{k+2}\left(\frac{\mathrm{N}}{\varepsilon_{c t 1}}\right)^{k}\left(h-\frac{\varepsilon_{c(1)}}{\mathrm{N}}\right)^{k+2} .
\end{gathered}
$$

Compression inner tension in the upper plate, rib and a part of a lower plate before the crack occurrence.:

$$
\begin{array}{r}
N_{c}=\int_{F} \sigma_{c} d F=\int_{0}^{x_{1}} f_{c}\left(2 b_{e f f}+b_{w}\right) \sum_{k=1}^{5} a_{k}\left(\frac{\mathrm{N} x}{\varepsilon_{c 1}}\right) k d x-\int_{0}^{x_{1}-h_{e f f}} f_{c} 2 b_{e f f} \sum_{k=1}^{5}\left(\frac{\mathrm{N} x}{\varepsilon_{c 1}}\right)^{k} d x+ \\
+\int_{0}^{5} f_{c} 2 b_{e f} \sum_{k=1}^{5} a_{k}\left(\frac{\mathrm{N} x}{\varepsilon_{c 1}}\right)^{k} d x=f_{c}\left(2 b_{e f f}+b_{w}\right) \sum \frac{a_{k}}{k+1}\left(\frac{\mathrm{N}}{\varepsilon_{c 1}}\right)^{k}\left(\frac{\varepsilon_{c(1)}}{\mathrm{N}}\right)^{k+1}- \\
-f_{c} 2 b_{\text {eff }} \sum_{k=1}^{5} \frac{a_{k}}{k+1}\left(\frac{\mathrm{N}}{\varepsilon_{c 1}}\right)^{k}\left(\frac{\varepsilon_{c(1)}}{\mathrm{N}}-h_{e f f}\right)^{k+1}+f_{c} 2 b_{e f} \sum \frac{a_{k}}{k+1}\left(\frac{\mathrm{N}}{\varepsilon_{c 1}}\right)^{k}\left(h_{e f}+\frac{\varepsilon_{c(1)}}{\mathrm{N}}-h\right)^{k+1} .
\end{array}
$$

The inner moment cause by this tension:

$$
\begin{gathered}
M_{c}=\int_{F} \sigma_{c} x d F=\int_{0}^{x_{1}} f_{c}\left(2 b_{e f f}+b_{w}\right) \sum_{k=1}^{5} a_{k}\left(\frac{\mathrm{N} x}{\varepsilon_{c 1}}\right) k x d x- \\
-\int_{0}^{x_{1}-h_{e f f}} f_{c} 2 b_{\text {eff }} \sum_{k=1}^{5}\left(\frac{\mathrm{N} x}{\varepsilon_{c 1}}\right)^{k} x d x+\int_{0}^{h_{e f}-\left(h-x_{1}\right)} f_{c} 2 b_{\text {ef }} \sum_{k=1}^{5} a_{k}\left(\frac{\mathrm{N} x}{\varepsilon_{c 1}}\right)^{k} x d x=
\end{gathered}
$$




$$
\begin{gathered}
=f_{c}\left(2 b_{e f f}+b_{w}\right) \sum \frac{a_{k}}{k+2}\left(\frac{\mathrm{N}}{\varepsilon_{c 1}}\right)^{k}\left(\frac{\varepsilon_{c(1)}}{\mathrm{N}}\right)^{k+2}-f_{c} 2 b_{e f f} \sum_{k=1}^{5} \frac{a_{k}}{k+2}\left(\frac{\mathrm{N}}{\varepsilon_{c 1}}\right)^{k}\left(\frac{\varepsilon_{c(1)}}{\mathrm{N}}-h_{e f f}\right)^{k+2}+ \\
+f_{c} 2 b_{e f} \sum \frac{a_{k}}{k+2}\left(\frac{\mathrm{N}}{\varepsilon_{c 1}}\right)^{k}\left(h_{e f}+\frac{\varepsilon_{c(1)}}{\mathrm{N}}-h\right)^{k+2} .
\end{gathered}
$$

After the cracks occurrence a gradual subtraction of a stretched plate's part is taken into account. The deformations on top of the crack will be considered as equal to the top ones under the stretch. In that case the equation (1) looks like the following:

$$
\begin{gathered}
N_{t}=\int_{F} \sigma_{c t} d F=\int_{0}^{x_{t}} f_{c t}\left(2 b_{e f}+b_{w}\right) \sum_{k=1}^{5} a_{k}\left(\frac{\mathrm{N} x}{\varepsilon_{c t 1}}\right)^{k} d x= \\
=f_{c t}\left(2 b_{e f}+b_{w}\right) \sum \frac{a_{k}}{k+1}\left(\frac{\mathrm{N}}{\varepsilon_{c t 1}}\right)^{k}\left(\frac{\varepsilon_{c t 1}}{\mathrm{~N}}\right)^{k+1} .
\end{gathered}
$$

In which $x_{t}=\frac{\varepsilon_{c t 1}}{\mathrm{~N}}$ - the height of the lower plate above the top of the crack.

Corresponding inner moment:

$$
\begin{gathered}
M_{t}=\int_{F} \sigma_{c t} x d F= \\
=\int_{0}^{x_{t}} f_{c t}\left(2 b_{e f}+b_{w}\right) \sum_{k=1}^{5} a_{k}\left(\frac{\mathrm{N} x}{\varepsilon_{c t 1}}\right)^{k} x d x=f_{c t}\left(2 b_{e f}+b_{w}\right) \sum \frac{a_{k}}{k+2}\left(\frac{\mathrm{N}}{\varepsilon_{c t 1}}\right)^{k}\left(\frac{\varepsilon_{c t 1}}{\mathrm{~N}}\right)^{k+2} .
\end{gathered}
$$

The equilibrium equation of the external forces looks like the:

In which $N$-external compressing force.

$$
N_{t}-N_{c}+N=0
$$

Moments equilibrium equation:

In which $M=N e_{0}$.

$$
M_{t}-M_{c}+M=0
$$

The load bearing capacity of the concrete blocks is calculated by using the formulas (1)-(8) in MS Excel according to the gradual approach method. The calculation resulted into the data about tenseddeformation condition of the blocks from the beginning of loading up to collapse. The criteria for collapse is an equilibrium loss between internal and external forces, which is reflected as maximums in the "force vs. curvature” graph. (Fig. 5).

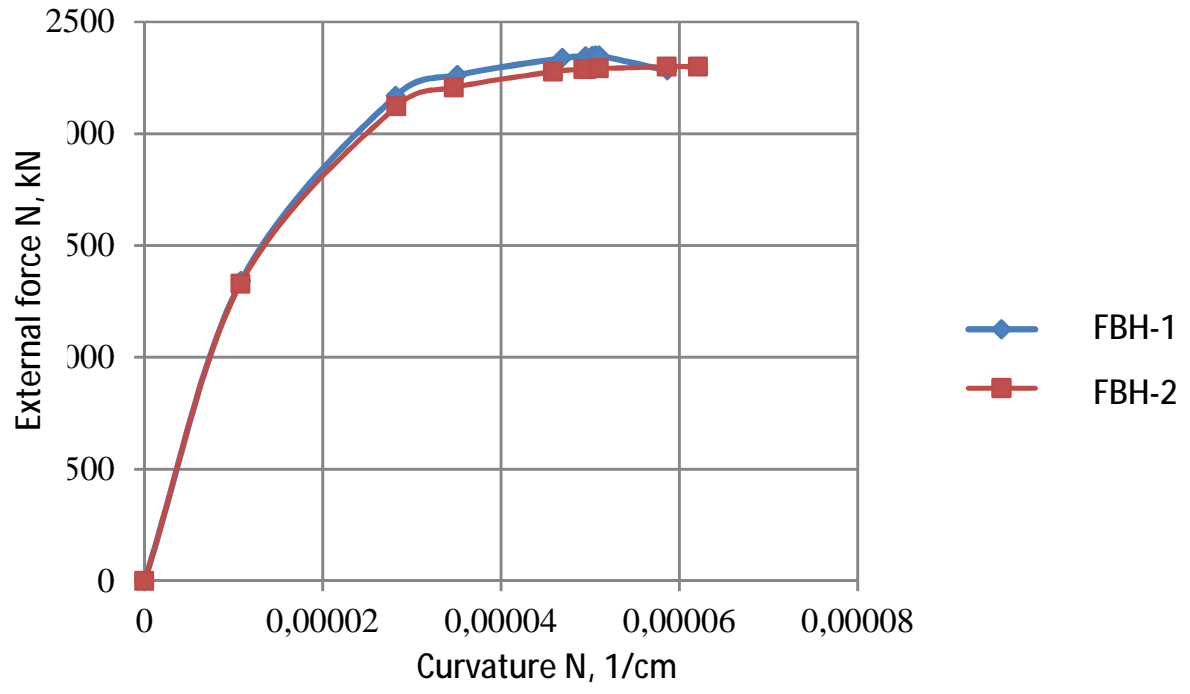

Fig. 5. Relation of the external force to the blocks' curvature 
According calculation for the FBH-1 block the cracks occurred under relative $\varepsilon_{c t 1}=0.0001286$ and the force of $N_{c r}=2169.125 \mathrm{kN}$. The block's load bearing capacity is $N_{u}=2350.9 \mathrm{kN}$. Under this tension the height of a compressed zone is $x_{1}=32.17 \mathrm{~cm}$, the height of a stretched zone is $x_{t}=2.52 \mathrm{~cm}$, the relative deformations of the ending compressed fibers are $\varepsilon_{\mathrm{c}(1)}=0.00164$, which is higher than $\varepsilon_{\mathrm{c} 1}=0.00153$. The FBH-2 block has got its cracks under its relative deformations of $\varepsilon_{c t 1}=0.000149$ and force of $N_{c r}=2122.17 \mathrm{kN}$. The load bearing capacity is $N_{u}=2299.60 \mathrm{kN}$. Under these tentions the height of a compressed zone is $x_{1}=32.21 \mathrm{~cm}$, the height of a stretched zone is $x_{t}=2.01 \mathrm{~cm}$, the relative deformations of the ending compressed fibers are $\varepsilon_{\mathrm{c}(1)}=0.002$, which is higher than $\varepsilon_{\mathrm{c} 1}=0.00149$.

The results, obtained by calculation with the deformation method are theoretical factors of crack occurrence and load bearing capacity exceeding, were compared to the corresponding sample test results. The comparison presented in the Table.

Comparison of experimental and theoretical values of bearing capacity and crack formation

\begin{tabular}{|c|c|c|c|c|c|c|}
\hline \multirow{2}{*}{ Block type } & \multicolumn{3}{|c|}{ Load bearing capacity } & \multicolumn{3}{c|}{ Crack occurence } \\
\cline { 2 - 7 } & $\mathrm{N}_{\mathrm{u}}^{\exp }, \kappa \mathrm{H}$ & $\mathrm{N}_{\mathrm{u}}^{\mathrm{th}}, \kappa \mathrm{H}$ & $\frac{\mathrm{N}_{\mathrm{u}}^{\mathrm{th}}}{\mathrm{N}_{\mathrm{u}}^{\exp }}$ & $\mathrm{N}_{\mathrm{cr}}^{\text {exp }}, \kappa \mathrm{H}$ & $\mathrm{N}_{\mathrm{cr}}^{\mathrm{th}}, \kappa \mathrm{H}$ & $\frac{\mathrm{N}_{\mathrm{cr}}^{\text {th }}}{\mathrm{N}_{\mathrm{cr}}^{\exp }}$ \\
\hline FBH-1 & 2075.0 & 2350.4 & 1.12 & 1896.2 & 2169.1 & 1.14 \\
\hline FBH-2 & 2286.0 & 2299.6 & 1.01 & 1988.7 & 2122.2 & 1.07 \\
\hline
\end{tabular}

As one can see in the table, theoretical results slightly surpass the test results, especially for the FBH-1 block - from $12 \%$ tо $14 \%$. For FBH-2 block this surpass is lower - до $7 \%$.

\section{Conclusions}

The research conducted for two types of hollow concrete blocks. A deformation method was developed to calculate an impact of off-center external load with consideration of idealized diagram for concrete stretched deformations.

The calculation using a developed method for test hollowed concrete blocks has showed a satisfactory matching experimental data of load bearing capacity and cracking resistance.

\section{Reference}

Malinina L. A., Folomeev A. A. (1985). Energy intensity of heavy concrete for precast and monolithic structures. Overview, 49. Moscow (in Russian Federation).

Reinforced concrete and ecology. Concrete and reinforced concrete. (1993). (Vol. 3, pp. 30-31).

Malyugin V. I. (1958). Efficiency of precast concrete in construction. Moscow (in Russian Federation).

Efficient zero cycle constructs for high-rise buildings. Concrete and reinforced concrete. (1975). (Vol. 8, pp. 38-40).

Report on NIR "Experimental study of hollow-core block panels of basement walls for residential and public buildings”. Lviv Polytechnic Institute. (1989).

Shmukler V. S., Molodchenko G. A., Burak N. P., Lugchenko E. I. (2007). Concrete blocks with rational parameters. Scientific Bulletin of Construction. (Vol. 42).

Akramul K. (1994). Study of the stress state and optimization of the parameters of concrete blocks with complex geometry. Abstract. Dissertation for the degree of candidate of technical sciences, 18. Poltava (in Ukraine).

Luhchenko O. I. (2009). Rational hollow concrete and reinforced concrete structures: abstract of the dissertation for the degree of Candidate of Technical Sciences: specialty 05.23.01, 22. Kharkiv (in Ukraine).

Tetior A. N. (1991). Effective foundation designs, 276. Kiev: UMK VO (in Ukraine).

Bau-Innovation Gesellschaftmobil \& Co. KG. ISOPLUS-EXTRA. (1991). 2.

Melnyk I. V. Method of manufacturing hollow concrete and reinforced concrete products Declaratory patent for invention. State Department of Intellectual Property. (Bull. No. 7-II from 15.12.2000 y).

Melnyk I. V., Pankiv M. I. (1999). Effective basemant wall blocks. Resource-saving materials, structures, buildings and structures, 212-217. Rivne (in Ukraine). 
Melnyk I. V. (2009). Strength of hollow foundation concrete blocks at different test shemes. Resourcesaving materials, structures, buildings and structures. (Vol. 19, pp. 198-2006).

Bambura A. M. (2006). Experimental bases of applied deformation theory of reinforced concrete: abstract of the dissertation for the degree of Doctor of Technical Sciences: specialty. 05.23.01, 39. Kharkiv: KhDTUB (in Ukraine).

І. В. Мельник', В. В. Білозір 4 , І. А. Біденко ${ }^{4}$, Р. А. Шуляр ${ }^{2}$, В. П. Партута ${ }^{3}$ Національний університет “Львівська політехніка",

1,3 кафедра автомобільних доріг та мостів

${ }^{2}$ кафедра будівельних конструкцій та мостів,

4 Львівський національний аграрний університет

\section{НЕСУЧА ЗДАТНІСТЬ І ТРІЩИНОСТІЙКІСТЬ ПОЗАЦЕНТРОВО СТИСНУТИХ БЕТОННИХ ПОРОЖНИСТИХ БЛОКІВ}

(C) Мельник I. В., Білозір В. В., Біденко I. А., Шуляр Р. А., Партута В. П., 2020

Дослідження стосуються бетонних порожнистих блоків стін підвалів, які широко використовували і використовують в практиці будівництва. Показано, що навіть для середньоповерхових і багатоповерхових будівель міцність бетонних блоків використовуються лише на 10-30 \%. Тому масивні фундаментні блоки доцільно виготовляти порожнистими.

За конструкцією оптимізовані блоки можна об’єднати в такі групи: 3 крупними порожнинами, відкритими знизу, з вертикальними закритими і наскрізними порожнинами, горизонтальними порожнинами і ребристі.

Розроблені конструкції ефективних блоків стін підвалів потенційно дають можливість значно облегшити їх і зекономити бетон. Проте майже всі запропоновані рішення не знайшли широкого використання на практиці - в основному внаслідок технологічних проблем. Необхідно продовжити пошук ефективних конструктивно- технологічних рішень блоків стін підвалів, та їх дослідження.

У статті відображено результати експериментально-теоретичних досліджень фундаментних блоків двох типів: 3 двома відкритими зверху порожнинами марки ФБП-1 та з 4-ма закритими порожнинами марки ФБП-2. В блоці ФБП-2 порожнини улаштовані з використанням арболітових вставок. Така конструкція блоків є доцільною для зовнішніх стін підвалів, оскільки покращує теплотехнічні характеристики стіни.

Випробовували блоки у складі 3-х ярусної стінки загальною висотою 1,8 м на позацентрово прикладене навантаження. Натурні випробування блоків дозволили отримати їхні фактичні значення міцності і тріщиностійкості.

Розрахункова несуча здатність і тріщиностійкість блоків визначали за деформаційною методикою згідно з чинними нормативними документами з врахуванням і ідеалізованої діаграми деформування бетону за розтягу.

Розрахунок за розробленою методикою натурних порожнистих блоків показав задовільну збіжність з експериментальними даними за показниками несучої здатності і тріщиностійкості.

Ключові слова: фундаментні порожнисті блоки, несуча здатність, експериментальні дослідження, деформаційний метод, діаграми деформування. 